\title{
ANÁLISE DE UMA CRÔNICA PRODUZIDA POR UM ALUNO NO AMBIENTE VIRTUAL DE APRENDIZAGEM-AVA/ Direito e INTELIGÊNCIA ARTIFICIAL
}

\author{
ANALYSIS OF A CHRONICLE PRODUCED BY A STUDENT IN THE VIRTUAL LEARNING \\ ENVIRONMENT/LAW AND IA
}

ANÁLISIS DE UNA CRÓNICA PRODUCIDA POR UN ALUMNO EN EL AMBIENTE VIRTUAL DE APRENDIZAJE-AVA/DERECHO YIA.

\author{
Carla Eugenia Caldas Barros ${ }^{1}$ \\ Genilma Dantas Andrade ${ }^{2}$ \\ Rodrygo Besteti de Campos ${ }^{3}$
}

RECEBIBO 29/05/2019

APROVADO 30/06/2019

PUBLICADO 01/07/2019

Editor Responsável: Carla Caldas

Método de Avaliação: Double Blind Review

E-ISSN: 2316-8080

DOI: 10.16928

\section{RESUMO}

Este artigo tem como objetivo analisar uma crônica produzida por um estudante através do Ambiente Virtual de Aprendizagem-AVA e como o uso das novas tecnologias está sendo integrado à prática pedagógica. $\mathrm{O}$ gênero literário-crônica foi escolhido para o presente artigo, por trazer a concisão, o humor, a despretensão temática, a gratuidade e a descrição poética das questões do cotidiano. Os procedimentos metodológicos utilizados foram levantamento do material bibliográfico, constituição e análise do corpus. Procurou-se fundamento teórico em autores que desenvolveram estudos sobre o gênero crônica, a escrita e o uso das novas tecnologias e IA no ensino, a exemplo de Bakhtin (1979, 2003), Fonseca (2011), Gnerre (1998), Dallari (2010), Dorsa (2010), Rocha (2019), Levy (1999), Puren (2009. O uso dos recursos tecnológicos requer trabalhar em sala de aula com investigação,

\footnotetext{
${ }^{1} \operatorname{Prof}^{\mathrm{a}} \mathrm{Dr}^{\mathrm{a}}$ Titular em Direito pela Universidade Federal de Sergipe. E-mail: carlaeugenia2010@gmail.com, artigos@pidcc.com.br, https://orcid.org/0000-0002-5818-5824, ID Lattes: 9788239647524103.

2 Mestra do PPGL/UFS. E-mail: genilmaandrade2014@gmail.com. ORCID: https://orcid.org/0000-0003-1737508X e link do lattes ID Lattes: 8710894854642945

${ }^{3}$ Graduado em Música/Licenciatura pela Universidade Federal de Maceió. E-mail:

rodrygobesteti@gmail.com, https://orcid.org/0000-0002-1217-7706 e http://lattes.cnpq.br/3410331234818609
} 
com interatividade e colaboração entre os envolvidos no processo de ensino-aprendizagem e que estimule um processo de mudança de comportamento tanto do professor quanto do aluno. Aspectos jurídicos de programas de computador e Inteligência Artificial de forma complementar ao assunto, bem como a criação de uma personalidade robótica no ordenamento jurídico brasileiro.

PALAVRAS-CHAVE: Ambiente Virtual de Aprendizagem. Crônica. Ensino. Novas Tecnologias e IA. Ética e Direito.

\section{ABSTRACT}

This article aims to analyze a chronicle produced by a student through the Virtual Learning Environment-AVA and how the use of new technologies is being integrated into pedagogical practice. The chronic literary genre was chosen for bringing concision, humor, thematic unpretentiousness, gratuitousness and poetic description of everyday issues. The methodological procedures used were survey of the bibliographic material, constitution and analysis of the corpus. We sought a theoretical foundation in authors who developed studies on the chronic genre, writing and the use of new technologies in teaching, such as Bakhtin (1979, 2003), Fonseca (2011), Gnerre (1998), Dallari Dorsa (2010), Rocha (2019), Levy (1999), Puren (2009). The use of technological resources requires working in the classroom with research, interactivity and collaboration among those involved in the teaching-learning process and stimulating a process of behavior change both of the teacher and of the student, as well as the creation of a robotic personality in the Brazilian legal system.

KEY-WORDS: Virtual learning environment. Chronic. Teaching. New Technologies and AI. Ethich and Law

\section{RESUMEN}

Este artículo tiene como objetivo analizar una crónica producida por un estudiante a través del Ambiente Virtual de Aprendizaje-AVA y cómo el uso de las nuevas tecnologías está siendo integrado a la práctica pedagógica. El género literario crónico fue escogido por traer la concisión, el humor, la despretensión temática, la gratuidad y la descripción poética de las cuestiones de lo cotidiano. Los procedimientos metodológicos utilizados fueron el levantamiento del material bibliográfico, constitución y análisis del corpus. En el caso de Bakhtin (1979, 2003), Fonseca (2011), Gnerre (1998), Dallari (2010), se presentó un fundamento teórico en autores que desarrollaron estudios sobre el género crónico, la escritura y el uso de las nuevas tecnologías en la enseñanza, a ejemplo de Bakhtin (1979, 2003) , Dorsa (2010), Rocha (2019), Levy (1999), Puren (2009.) El uso de los recursos tecnológicos requiere trabajar en aula con investigación, con interactividad y colaboración entre los involucrados en el proceso de enseñanza-aprendizaje y que estimule un proceso de cambio de comportamiento tanto del profesor y del alumno, así como la creación de una personalidad robótica en el ordenamiento jurídico brasileño.

PALABRAS-CLAVE: Entorno Virtual de Aprendizaje. Crónica. Educación. Nuevas tecnologías e IA. Ética e Derecho. 


\section{INTRODUÇÃO}

A inteligência humana é estudada há mais de 2000 anos atrás. Neste ponto, a filosofia trouxe várias contribuições para o entendimento da inteligência, ao perquirir como se desenvolviam os processos de aprendizado, lembranças, visão, audição e raciocínio no cérebro e comportamentos humanos. O nosso interesse como humanidade não se restringia tão somente a nos compreendermos, mas queríamos ir mais longe, criar nossa própria criatura, criaturas que fossem capazes de nos imitar, de se comportar de forma aparentemente inteligente. Não nos limitamos a querer criar criaturas /máquinas que funcionassem pelo simples processamento numérico (inteligência computacional) para ajudar a humanidade em suas atividades. Os seres humanos não se conformando com as limitações de velocidade de seus cérebros, (a humanidade é uma aprendiz lenta) com o desenvolvimento dos avanços tecnológicos, está estendendo a sua humanidade a máquinas, criando sua própria criatura com a inteligência artificial ${ }^{4}$.

E, para se chegar à construção de uma máquina pensante, é mister, ab initio, definir o que seja inteligência, linguagem e aprendizado. E, existem várias formas, do ser humano expressar sua inteligência, seja através da língua escrita e ou língua oral. Como então caminhamos da linguagem escrita e oral para a linguagem computacional? Óbvio que, inicialmente, deverá ter um ser humano ensinando ( programando) um único computador a realizar determinada tarefa. Este programa por sua vez poderá ser copiado e ensinar a outros computadores aquela tarefa, sem precisar tomar decisões, esta por sua vez é uma das questões éticas a ser enfrentada pela ética para discutir delimitação de riscos, controle, vigilância e outros. É neste ambiente atual de desenvolvimento da inteligência $\operatorname{artificial}^{5}$ que a mesma é utilizada, aplicada na Educação. São criados sistemas educacionais com o fim primordial de aprimorar o ensino e a aprendizagem. As novas tecnologias e o uso da mesma em escolas vêm mudando o perfil de uso destas novas tecnologias, como rede wifi, celular e tablete e armazenamento de conteúdo em nuvens. No entanto, o educador precisa dominar as técnicas da linguagem escrita, e oral para enfim dominar as novas tecnologias e aplicá-las

\footnotetext{
4 A inteligência artificial é um ramo, porém não exclusivo da ciência da computação, que segundo Maria Carolina Monard et al , " cujo interesse é fazer os computadores pensar ou se comportar de forma inteligente. ( ...) IA também está relacionada com psicologia, biologia, lógica, matemática, linguística, engenharia, filosofia , entre outras áreas científicas, como a linguagem natural, reconhecimento de padrões - com o objetivo de fornecer ao computador as habilidades para efetuar funções antes desempenhadas apenas através da inteligência Humana" Disponível em: http://dcm.ffclrp.usp.br/ augusto/publications/2000-laptec.pdf. Acesso em: 02 abr. 2019, p. 2-3. A inteligência artificial, termo cunhado na década de 50 do século passado, traz inquietação para a direção em que a humanidade se desenvolve.

${ }^{5} \mathrm{O}$ termo IA entrou no mundo da computação e de áreas transversais pelas mãos e criatividade de J. McCarthy em 1956, o qual fora um dos fundadores desta área do conhecimento.
} 
em sala de aula alinhadas com as demandas tecnológicas educacionais do século XXI, de forma não excludente, para formar cidadãos capazes de enfrentar os desafios da pósmodernidade. É visível a forte preponderância da Inteligência artificial na Educação em decorrência do seu caráter interdisciplinar como também em sede do Direito, pois várias indagações passam a existir e as quais precisam de respostas efetivas normatizadas como resposta à vida em sociedade em época de Big Data ${ }^{6}$. É fato que o "processo mental" da inteligência artificial é imensamente mais rápido que o processo mental humano. Este fato deve manter os seres humanos em estado de alerta, de vigilância na variedade e velocidades que a IA é produzida e auto reproduzida pelos sistemas computacionais inteligentes (software) com capacidade de decisão e não simplesmente reproduzir programas numéricos e sim reproduzir o processamento simbólico. E a vigilância deve ser redobrada para fiscalizar quais os valores éticos e morais do programador e como ele está manipulando o conhecimento programado na IA que segundo a ciência da computação é a tecnologia chave para o software do futuro. Futuro este que deve ser fiscalizado, controlado pelos seres humanos.

As línguas são elementos fundamentais na vida dos cidadãos e para o bom funcionamento democrático das sociedades, seja pelo enriquecimento intelectual, cultural, econômico, comercial, militar ou social. O processo de ensino e aprendizagem de uma língua pressupõe a utilização de algum método que leve ao seu alcance. Assim, ao longo dos anos, com a evolução dos estudos sobre esse processo foram surgindo diversas metodologias, de modo que umas substituíram outras na busca de superar as limitações deixadas pelas anteriores, ponderando em torno dessas metodologias, fatores importantes que foram e ainda são postulados sob vários aspectos como os papéis desempenhados por professores e alunos, intenção de comunicação destes fatores na concepção de língua desenvolvida em cada época e lugar da cultura na aprendizagem.

As situações de ensino podem variar drasticamente de uma época a outra. Atualmente, percebe-se que as tecnologias estão integradas no cotidiano dos estudantes e, por isso, é fundamental sua utilização no processo do conhecimento e da aprendizagem. Apesar de sua importância, são pouco utilizadas em sala de aula como uma ferramenta para auxiliar no processo. Desse modo, os professores devem buscar sua própria formação para utilizar os ambientes virtuais como recurso pedagógico, pois, é de suma importância o uso das novas tecnologias em sala de aula, por facilitar o envolvimento do educando e melhorar sua aprendizagem e suas habilidades no uso destas ferramentas tecnológicas no processo de ensino-aprendizagem.

Este artigo tem como objetivo analisar um texto de gênero - crônica produzida por um estudante através do Ambiente Virtual de Aprendizagem-AVA e, como o uso das novas tecnologias interage positivamente à prática pedagógica. Além de utilizar uma linguagem coloquial, o aluno escreve de forma livre, capta com sua sensibilidade, fatos corriqueiros e singulares da vida, muitas vezes desprestigiados no cotidiano; este dado traz sempre uma

\footnotetext{
${ }^{6}$ No mês passado vindouro (abril de 2019) a Comissão Europeia conclamada com os anseios da sociedade da União Europeia, divulgou as Diretrizes Éticas para a Inteligência Artificial Confiável tanto para ressaltar seus benefícios como também enfrentar o debate dos riscos envolvidos pelo surgimento da IA com capacidade de pensar. Os mandamentos da IA na UE são estes: - garantia da supervisão e controle humano (os sistemas não devem limitar a autonomia humana porque senão estaríamos criando uma criatura que poderia ou pode extinguir a vida humana como atualmente conhecemos); - robustez e segurança (os algoritmos têm de ser capaz de lidar com erros); - privacidade e controle de dados (os utilizadores devem manter o controle dos seus dados e poder revogar o acesso); - responsabilização (capacidade de reconhecer erros e corrigi-los); - transparência, diversidade, não-discriminação e justiça, - promoção do bem-estar ambiental e social.
} 
visão crítica do fato tratado. Objetiva-se, ainda, examinar os diversos mecanismos textuais utilizados pelo autor, dentre eles a seleção lexical e seus efeitos para melhor interpretação de sua crônica. É importante considerar o texto enquanto unidade sociointeracional, individual e autônoma.

Para a construção desta pesquisa, escolheu-se a leitura e análise de textos de teóricos que trabalham com o Gênero Crônica, a escrita e o uso das Novas Tecnologias no ensino, a exemplo de Bakhtin (1979, 2003), Fonseca (2011), Gnerre (1998), Dallari (2010), Dorsa (2010), Rocha (2019), Levy (1999), Puren (2009). Os referidos autores foram preferidos pela sua bagagem intelectual sobre o tema integrado/agregado ao Ambiente Virtual de Aprendizagem-AVA, além dos livros para a análise de quais são os parâmetros éticos e jurídicos para a utilização de Inteligência Artificial (computador) na educação.

Para atender a proposta, organizou-se o texto em cinco partes: primeira, algumas considerações sobre a escrita no ocidente; segunda, trouxe informações básicas sobre os desafios da educação frente às novas tecnologias junto aos profissionais de educação envolvidos para enfrentamento destes novos desafios trazidos pela informática; na terceira sobre o gênero crônica e o recurso digital Ambiente Virtual de Aprendizagem, na quarta a metodologia e análise da crônica do estudante, considerando a seleção lexical e seus efeitos. Portanto, conforme afirmou Dorsa (2010, p. 4), é possível educar integrando mídia e educação [...] fazer educação usando todos os meios tecnológicos disponíveis, assim, as novas tecnologias, aliadas à práxis do ensino, aprimoram e dinamizam o processo educacional. E, por fim, na quinta analisar-se- á a interação com o ambiente virtual e quais devem ser os parâmetros éticos e implicações jurídicas no desenvolvimento e na utilização da IA.

"É interessante notar que o aprendizado automático, assim como os processos de aquisição de conhecimento que, na primeira fase da história da IA, eram realizadas explicitamente. Diretamente pelo ser humano, mas nesta outra fase é conseguido através de processos automatizados de extração de conhecimento. (...) Na fase atual, outras funções relevantes, como a percepção são consideradas, especialmente no tratamento dos Agentes inteligentes. Mais uma vez, as novas tecnologias, os novos algoritmos e os novos enfoques, ampliaram o leque de aplicações e têm proporcionado a solução de problemas que, sem o surgimento dessas áreas, dificilmente seriam possíveis."7

\section{A escrita no ocidente}

A História nos conta que a linguagem humana é um acontecimento que apareceu desde os primórdios, mas a invenção da escrita deu-se tardiamente, em comparação à linguagem. Nessa perspectiva histórica da oralidade e da escrita, trataremos os aspectos mais relevantes desses fenômenos. Uma das finalidades da linguagem é a de veicular informações, seja por via oral, seja por via escrita. Portanto, a posição central da linguagem é a função de comunicação entre os seres humanos. No fim da Idade Média, houve um trabalho voltado às exigências políticas e culturais referente à variedade linguística e ao poder da escrita. Isso se justifica pelas grandes diferenças entre as variedades linguísticas e o latim (que dominou o mundo ocidental devido à expansão do Império Romano), que era modelo de língua e poder daquela época. Segundo Gnerre (1998), esse modelo passou por um processo de regularização das classes gramaticais. "Nas obras de Rei Alfonso X, que

\footnotetext{
${ }^{7}$ MONARD, Maria Carolina et al, op. cit. p.
} 
'traduzia' no século XIII do latim para o castelhano, encontramos constantemente termos emprestados do latim e introduzidos na variedade usada com uma explicação anexa: tirano, que quieredezirrey cruel" (GNERRE, 1998, p. 11). No entanto, foi um trabalho bastante complexo colocar uma variedade oral nas formas da língua escrita, por causa das estruturas sintáticas do latim. Assim, observamos porque nos textos mais antigos, as ambiguidades ocorriam. É devido à complexidade em adequar a oralidade na escrita e ao fato de que algumas construções usadas na língua escrita estavam ainda em fase de elaboração e definição (GNERRE, 1998, p.12).

Outro fato relevante desse aspecto foi o evento fundador da possibilidade de existência de culturas letradas, que ocorreu com o surgimento do alfabeto na Grécia Antiga. Natural de uma escrita econômica, no sentido de poder ser aprendida de modo relativamente rápido, traço fundamental da escrita alfabética grega que deu uma virada nas culturas e que mudou o conteúdo da mente humana, ou seja, uma consciência letrada. Daí sua importância. Por isso, todas as ciências têm fundamento no alfabeto, pois é a grande fonte de propagação da informação, no qual o ser humano, o mundo e a sociedade estão inseridos. É interessante observar que a fixação de uma norma, ou seja, da gramática, se deu pelo processo da variedade já constituída como língua escrita e com a tradição gramatical greco-latina. Diante disso, temos a legitimidade de uma variedade linguística de poder. Isso aconteceu porque a tradição gramatical, até o início da idade moderna é relacionada somente às duas línguas clássicas: a grega e a latina.

Em meados do século $\mathrm{XV}$, com a expansão colonial ibérica, a valorização das variantes linguísticas escritas ganhou força, pois estavam relacionadas aos poderes centrais, tanto da Igreja como do Estado. Gnerre (1998) ao citar Nebrija, afirmava que "a língua sempre acompanhou a dominação e a seguiu, de tal modo que juntas começaram, juntas cresceram, juntas floresceram e, afinal, sua queda foi comum". João de Barro que, quase cinquenta anos depois, apresentava uma visão mais articulada: a língua é um instrumento para a difusão da "doutrina" e dos "costumes", mas não é somente instrumento de propagação, pois "as armas e padrões portugueses [...] materiais são e pode-os o tempo gastar, pero não gastará a doutrina, costumes e a linguagem que os portugueses nestas terras deixaram" (GNERRE, 1998, p.14).

Perante essa explanação, cabe-nos entender que a língua é o fio condutor da perpetuação da presença portuguesa em território brasileiro. É o que experimentamos até hoje. A Língua Portuguesa, falada e escrita, não estagnou. Outra consideração importante diz respeito à língua dos gramáticos, que é fruto gerado e que tem a finalidade de impor sobre a diversidade, tanto oral como escrita, ou seja, a língua construída por longos anos para ser utilizada como língua do poder político e cultural. Sobre esse aspecto, Bakhtin (2008) aponta as relações entre a sistematização formalista e a produção cultural:

Os criadores - iniciadores de novas correntes ideológicas - nunca sentem necessidade de formalizar sistematicamente. A sistematização aparece quando nos sentimos sob a dominação de um pensamento autoritário aceito como tal. É preciso que a época de criatividade acabe: só aí é que então começa a sistematização-formalização; é o trabalho dos herdeiros e dos epígonos dominados pela palavra alheia que parou de ressoar. A orientação da corrente em evolução nunca pode ser formalizada e sistematizada. Esta é a razão pela qual o pensamento gramatical formalista e sistematizante desenvolveu-se com toda plenitude e vigor no campo das línguas mortas e, ainda, somente nos casos em que essas línguas perderam, até certo ponto, sua influência e seu caráter formal-sistemático foi inevitavelmente coagida a adotar em relação às línguas vivas uma posição conservadora e acadêmica, isto é, a tratar a língua viva como se fosse algo acabado, o que 
implica uma atitude hostil em relação a todas as inovações linguísticas (BAKHTIN, [1979], 2008, p. 89).

Vale ressaltar que a escrita foi uma das grandes criações da humanidade, pois surgiu da necessidade do homem em criar registros, armazenar dados e preservar sua história. É incontestável que, para ela aparecer, foi numa sociedade fortemente hierarquizada. É sabido, através da História, que a escrita não é acessível às pessoas comuns porque seus trabalhos não exigem tal conhecimento. Assim, o domínio da escrita fica por conta das pessoas de classe mais alta. $\mathrm{O}$ auge da escrita, por parte de todos os cidadãos, ocorreu no final do século XIX na Europa, devido a grandes mudanças da sociedade com a Revolução Industrial, seus avanços tecnológicos, entre outros. Trindade (2016) diz que:

Nos dias de hoje o não conhecimento da leitura e da escrita (analfabetismo) é sinônimo de fracasso escolar e consequentemente do fracasso do indivíduo como ser social, uma vez que nos padrões da sociedade atual é somente através da escolaridade que a pessoa poderá vir a "ser alguém", ou seja, ter acesso à cultura, dinheiro, poder e felicidade (TRINDADE, 2016, p. 08).

A incontestabilidade do poder hierárquico vai perdendo força diante do poder tecnológico - estamos em processo. É relativo esse poder. Basta que se observe o que e como se escreve nas "redes sociais". Assim, esses sujeitos fazem com que a escrita não atenda mais aos anseios do mundo contemporâneo. Medeiros (2016) faz uma análise acerca das rupturas que ocorreram no processo da escrita durante a história. Assim temos:

A primeira dessas rupturas refere-se à ordem dos discursos. Na cultura impressa, como a conhecemos, essa ordem se estabelece a partir da relação entre tipos de objetos (os livros, o diário, a revista), categorias de textos e formas de leitura. Tal vinculação está arraigada a uma história de longa duração da cultura escrita e provém da sedimentação de três inovações fundamentais: em primeiro lugar, entre os séculos II e IV, a difusão de um novo tipo de livro, que ainda é o nosso, isto é, o livro composto de folhas e páginas reunidas dentro de uma mesma encadernação que chamamos códex e que substitui os rolos da Antiguidade grega e romana; em segundo, no final da Idade Média, nos séculos XIV e XV, o aparecimento do "livro unitário", ou seja, a presença, dentro de um mesmo livro manuscrito, de obras compostas em língua vulgar por único autor, enquanto antes essa lista caracterizava apenas as autoridades canônicas antigas e cristãs e as obras em latim; e, finalmente, no século XV, a invenção da imprensa, que continua sendo até agora a técnica mais utilizada para a reprodução do escrito e a produção de livros (MEDEIROS, 2016, p. 24).

Sendo assim, somos herdeiros dessa história. Vemos a percepção da cultura escrita e impressa se basear em diferentes objetos, por livros, cartas, diários, documentos, etc., na qual, a ordem dos discursos se transforma intensamente com o advento da textualidade eletrônica. Dessa maneira, 
Todos os textos, sejam eles de qualquer gênero, são lidos em um mesmo suporte (a tela do computador) e nas mesmas formas (geralmente as que são definidas pelo leitor). Cria-se assim uma continuidade que não mais diferencia os diversos discursos a partir de sua própria materialidade. Surge desta forma uma primeira inquietação ou confusão dos leitores, que devem enfrentar o desaparecimento dos critérios imediatos, visíveis, materiais, que lhes permitiam distinguir, classificar e hierarquizar os discursos (MEDEIROS, 2016, p. 18).

Essa ordem do discurso institui uma nova técnica de difusão da escrita, instiga uma nova relação com os textos e estabelece uma nova forma de inscrição, não descartando assim, uma revolução da modalidade, tanto técnica da produção do escrito, como da compreensão das entidades textuais, das estruturas e formas mais significativas da escrita. Desse modo, a Internet criou um novo paradigma de conectividade universal, dando um novo conceito de valor, o da informação, que deveria acarretar um cuidado maior no conteúdo, na produção e no processo linguístico, pois o ambiente de rede não assegura a seleção, o acesso, a agregação e a autoridade que está a produzir essa informação. Pontos estes indispensáveis para garantir um valor de navegação, não permitia ao leitor escrever enquanto lia, mas o livro impresso e manuscrito permitia folhear, citar trechos com precisão, marcar índices e com uma leitura fragmentada, não deixava de compreender a totalidade da obra identificada por sua própria materialidade.

A partir do século passado, nos anos 90, foram desenvolvidos softwares. É nessa época que o uso da informática na educação começou a evidenciar na educação. Entretanto, esse fenômeno ficou em destaque com a revolução da internet, em que o computador passou a ser cada vez mais indispensável, principalmente, como porta de entrada para a rede mundial de computadores. Nesse contexto, Teixeira e Araujo (2019) afirmam que, "a informática na educação deixa de ser um diferencial para se tornar elemento chave entre pertencer a uma sociedade cada vez mais globalizada ou conectada ou estar alienado a esse mundo" (TEXEIRA e ARAUJO, 2019, p.02). Portanto, saber utilizá-la em prol da educação, é um dos desafios impostos aos educadores modernos e adaptá-los com o Ambiente Virtual de Aprendizagem- AVA $^{8}$.

\section{Os desafios da educação frente às novas tecnologias/Inteligência Artificial}

Hoje, ainda constatamos uma evolução constante das metodologias de ensino que aflui entre a evolução didática, a evolução social, a evolução tecnológica e seus usos, sobre o agir social. Isso implica a necessidade de explorar e desenvolver metodologias que articulam as novas Tecnologias de Informação e Comunicação (TIC) às estratégias didáticas no ensino de línguas como recurso pedagógico na formação de professores, para que estes se apropriem e realizem competências, mediante recursos inovadores, material didático e propostas de atividades significativas que leva em conta o agir social, tanto em sala de aula quanto em sociedade.

Essa nova orientação didática, no seu contexto político e educativo, vem promover a cooperação a nível nacional e internacional das instituições governamentais e não

\footnotetext{
${ }^{8}$ A utilização de novas tecnologias no processo ensino aprendizagem está intrinsecamente ligada aos sistemas tecnológicos educacionais. O conteúdo educacional vem sendo transformado com a utilização da IA.
} 
governamentais dedicadas no desenvolvimento de métodos de ensino e de avaliação no campo da aprendizagem das línguas modernas e a produção e uso de material multimídia. É necessário, no entanto, tomar medidas essenciais para concluir o estabelecimento de um sistema europeu eficaz de intercâmbio de informações que abranja todos os aspectos da aprendizagem, do ensino e da investigação de línguas, fazendo uso das tecnologias da informação. Em função disso Puren (2009) afirma que:

(...) l' importance politique aujourd'hui et dans l' avenir du développement de domaines d' action particuliers tel que les stratégies de diversification de l' apprentissagem des langues afin de promouvoir le plurilinguisme em contexte pan-européen et a attiré l' attention sur la valeur du développement des liens et des échanges éducatis et sur l' exploitation de tout le potentiel des nouvelles technologies de 1 ' information et de la communication (CECR, 2011, p.11).

No tocante às novas tecnologias de informação e comunicação, estamos vivendo um novo espaço de comunicação que tem proporcionado mudanças profundas na sociedade contemporânea. Tais mudanças transformam as relações interpessoais, toda forma de comunicação e também o ensino. Na década de 60 do século XX, as TIC já eram consideradas através dos métodos áudio-oral e $\mathrm{SGAV}^{9}$, como recursos pedagógicos, a exemplo de gravadores e projetores de imagem, todavia, é no início do século XXI com a Internet e a multimídia que seu uso se difunde amplamente nos diferentes estratos socioculturais.

Esse novo espaço de comunicação, chamado de ciberespaço e definido por Levy (1999) como rede, é o novo meio de comunicação que surge da interconexão mundial dos computadores. É através das tecnologias intelectuais que são transformadas várias funções cognitivas humanas, tais como: percepção, memória, imaginação, raciocínios, favorecendo assim, novas formas de acesso à informação, novos estilos de conhecimento, que são objetivadas em documentos digitais ou programas disponíveis na rede. Dessa forma, essas tecnologias intelectuais podem ser compartilhadas entre muitos indivíduos, aumentando o potencial de inteligência. Nesse contexto, segundo Levy (1999), as novas tecnologias da inteligência individual e coletiva mudam profundamente os dados do problema da educação e da formação, "sendo que a mola propulsora da transformação educacional não está intrinsicamente nas TIC, mas nas mudanças de valores, ideias e atitudes provocadas pelo seu uso na sociedade" (LEVY, 1999, p. 19).

Por esse motivo, grandes reformas são necessárias nos sistemas de educação e formação, mas o principal se encontra em um novo estilo de pedagogia, que favoreça simultaneamente as aprendizagens personalizadas e coletivas em rede. Nessa perspectiva, conforme Moran (2004), o professor é encorajado a tornar-se animador da inteligência

\footnotetext{
${ }^{9}$ A metodologia SGAV (Structural-Global Audio-Visual) é um método de ensino-aprendizagem criado na década de 1960 por P. Guberina e P. Rivenc. Baseado no behaviorismo, é baseado no uso de uma trilha sonora e uma tira de filme. Seus princípios fundamentais são dar prioridade à comunicação oral em interação em detrimento da linguagem escrita, que aparece somente após um certo número de horas de aulas, e privilegiar uma abordagem situacional. O primeiro curso desenvolvido de acordo com este método, intitulado "Voices and Images of France", é publicado em 1962. Este método é planejado de acordo com seus designers rigorosos e científicos. Disponível em: https://sites.google.com/site/definitionspedagogie/definitions/s/sgav
} 
coletiva de seus grupos de alunos em vez de fornecedor direto de conhecimento, o aluno deixa de lado o papel outrora passivo e assume ativamente as rédeas de seu processo de aprendizagem (MORAN, 2004, p. 18).

Com a evolução das tecnologias de informação e seus usos (nos meios da web social: blogs, sites e aplicativos colaborativos), faz-se necessário o planejamento, a produção de materiais didáticos e a formação do docente. No entanto, na contramão dessa lógica, segundo Levy (1999, p.39) houve uma expansão da literatura meramente teórica e superficial desse assunto com pouco ou nenhum suporte empírico, pois a efetiva produção de materiais didáticos e sistemas de ensino parecem ter estacionado enquanto realidade virtual.

Atualmente podem ser utilizadas muitas ferramentas tecnológicas para auxiliar no aprendizado em sala de aula. A utilização dos recursos midiáticos poderá revolucionar a educação, mas, para isso, será importante que escola e os educadores entendam que "tecnologia de informação e comunicação compreende recursos tecnológicos que envolvem computadores e redes telemáticas (informática + telecomunicação), em especial a rede internet" (SILVA, 2010, p. 7). As novas tecnologias já estão contempladas no Currículo para a educação. Cabe aos gestores públicos inseri-las, com maior eficiência. Como se sabe, outras tecnologias sempre foram utilizadas nas escolas, conforme Moran (2004) afirma:

A forma como organizamos em grupo, em salas, em outros espaços: isso também é tecnologia. O giz que escreve na lousa é tecnologia de comunicação, e uma boa organização de escrita facilita - muito - a aprendizagem. A forma de falar, gesticular, de falar com os outros: isso também é tecnologia. O livro, a revista, o jornal, o gravador, o retroprojetor, a televisão, o vídeo são tecnologias importantes e muito mal utilizadas em geral (MORAN, 2004, p.153).

Outra ferramenta que está despontando como facilitador e incentivador da colaboração e produtividade na sala de aula é a Inteligência Artificial, que está se tornando parte integrante das escolas, assim como os computadores e a internet. Segundo Rocha (2019), a Inteligência Artificial (IA) é uma área das ciências da computação cujo objetivo é produzir dispositivos que simulem a capacidade humana de raciocinar, perceber, tomar decisões e resolver problemas. Ou seja, a partir de um estímulo do ambiente (mundo externo) há uma ação a ser realizada, baseada na análise de dados de interações anteriores. Hoje em dia, encontramos várias aplicações da Inteligência Artificial na vida real: desde jogos, programas de computador, aplicativos de segurança a sistemas informacionais, robótica (robôs auxiliares), dispositivos para reconhecimentos de escrita à mão e reconhecimento de voz, etc. (ROCHA, 2019, p. 01).

Conforme Rocha (2019), a Inteligência Artificial ou Inteligência Cognitiva (considerada como o próximo passo da IA) lança mão dos mesmos mecanismos que os humanos possuem para tomar decisões, assim a autora esclarece que:

Esse sistema recebe dados que são inseridos pelos humanos. Em seguida, trata esses dados (relaciona, categoriza) e, por meio de perguntas e respostas que são feitas por humanos, começa a entender a melhor forma de analisar aqueles dados para responder a essas perguntas. Quanto mais faz isso, mais tem a capacidade de responder perguntas complexas e de fornecer as possíveis respostas a essas perguntas. O último passo consiste 
em indicar qual seria a resposta mais adequada dentre todas as possíveis (ROCHA, 2019, p. 02).

Em vista disso, a IA tem se concretizado na esfera educacional e isso acontece através das chamadas plataformas adaptativas, ou seja, pelo simples fato de propor trilhas de aprendizado individualizadas, segundo seus conhecimentos prévios a respeito dos usuários. Para isso, ela coleta os dados de cada experiência de uso, analisa e propõe um percurso específico para o usuário, a partir do seu ponto de partida. Rocha (2019) afirma que isso é possível graças ao mapeamento realizado nos conteúdos daquela área de conhecimento e o estabelecimento de relações entre esses conteúdos. Segundo, Teixeira e Araújo (2019):

Com todo esse desenvolvimento é imposta à obrigação aos profissionais envolvidos em educação de se tornarem indivíduos capazes de atender as mais variadas exigências. Isso faz com que o sistema educação seja cobrado, sendo exigida uma formação completa, onde o indivíduo seja capaz de lidar com as mais variadas situações. Para isso, a escola tem de desdobrar-se para atender a grande demanda de exigências, e caso ela não dê conta de tais responsabilidades, essa escola será considerada incapacitada e inadequada para formar o "cidadão capaz" (TEXEIRA E ARAUJO, 2019, p. 03).

Sem este estudo aprofundado, não seria possível que uma plataforma construísse trilhas de aprendizagem que fizessem sentido do ponto de vista pedagógico. E isso se dá quando a plataforma está integrada à sala de aula. Assim sendo, o professor consegue identificar o quanto esses estudantes estão próximos ou distantes dos objetivos de aprendizagem previstos para aquele período (dia, semana, mês, bimestre etc.) e, com isso, terá condições de planejar as próximas experiências de aprendizagem com muito mais precisão (ROCHA, 2019, p. 03).

"Por muito tempo os profissionais em educação vêm buscando e experimentando formas de equacionar essas teorias com o dia a dia em sala de aula. A informática ou o uso do computador vem a ser mais uma ponte no estreitamento da relação teoria-prática. A versatilidade na manipulação do computador permite que o indivíduo possa vivenciar e realizar experimentos ou produzir textos, ou realizar pesquisas sobre temas aos quais nunca poderia ter acesso através de meios reais ou mesmo cuja realização demandaria uma infraestrutura inviável à maioria das escolas. Além disso, o computador permite tanto a realização de operações individuais, onde o educando vai navegando por assuntos do seu interesse quanto uma socialização através do relacionamento com pessoas distantes tanto geograficamente como muitas vezes culturalmente. Para que isso tudo aconteça é necessário um conhecimento mínimo no uso do computador, conhecimento esse facilitado pelo uso de interfaces cada vez mais simbióticas com o usuário. ${ }^{10}$

\section{Gênero/crônica e o recurso digital Ambiente Virtual de Aprendizagem - AVA}

\footnotetext{
${ }^{10}$ Núbia Poliane Cardoso Teixeira e Alberto Einstein Pereira de Araújo , INFORMÁTICA E EDUCAÇÃO: UMA REFLEXÃO SOBRE NOVAS METODOLOGIAS, Disponível em http://www.hipertextus.net/volume1/artigo13-nubia-alberto.pdf, acesso em 05 maio 2019, p.04.
} 
O gênero/crônica se desenvolve ao longo do século XIX, na França, resultado dos jornais que atuaram em sua capacidade múltipla, isto é, os jornais, como espaço propício ao debate das questões da sociedade, tornam-se o lugar favorável à multiplicidade de novas expressões e recursos linguísticos, artísticos e culturais. Assim, a crônica traz a concisão, o humor, a despretensão temática, a ironia, a gratuidade e, por fim, a descrição poética das questões do cotidiano.

Portanto, a crônica segue por outros caminhos no século XXI, há mais elementos que fazem do presente um período hostil ao lirismo. Luís Fernando Veríssimo decifra a comédia da vida privada e pública, utiliza essa nova roupagem da crônica em seus trabalhos, nos mais diferentes veículos de comunicação. $\mathrm{O}$ cronista propõe recriar aspectos do mundo, procura produzir uma conversa que parte de algum fato corriqueiro, de um acontecimento qualquer do dia a dia.

Vários especialistas afirmam que a crônica é um atrativo para leitores diversos e decorre de efeitos produzidos pela maneira que se referem ao leitor, "falando" a ele com intimidade, cumplicidade, amizade. Nesse sentido, Fonseca (2011) afirma que o texto da crônica demonstra bem o processo de construção de objetos, não do mundo, mas sim dos objetos discursivos, pois nessa "conversa", muitas vezes, o autor da crônica aproveita para mostrar ao leitor seu ponto de vista, para argumentar a favor de uma visão ou de uma opinião própria (FONSECA, [1992], 2011, p. 118).

Dessa maneira temos os gêneros virtuais que incluem o público - leitor, espectador, internauta e como todo gênero, o midiático é dialógico, o AVA e I A proporciona o desenvolvimento e distribuição de conteúdos diversos para cursos online e disciplinas semipresenciais para alunos em geral. Não se trata de um processo unilateral de emissão e recepção, todavia de uma interlocução, na qual ambos fazem, alternadamente, o papel de falante e ouvinte (DALLARI, 2010, p. 4).

É no AVA/ IA que o aluno poderá ser impactado por conteúdos e passará por todo o processo de aprendizagem, caso esteja inserido em um curso da modalidade de ensino online. Um AVA pode ser usado também como ferramenta para EAD (educação a distância), sendo usado em alguns casos para complementar aulas presenciais com conteúdos virtuais.

Nesse contexto, foi proposto, nesse ambiente virtual, que o estudante produzisse uma crônica, além de utilizar uma linguagem coloquial, ele escrevesse de forma livre. Objetivase, assim, examinar os diversos mecanismos textuais utilizados pelo autor, dentre eles a seleção lexical e seus efeitos para melhor interpretação de sua crônica. É importante considerar o texto enquanto unidade sócio-interacional individual e autônoma.

Apresentou-se ainda um material para o aluno que articula o gênero/crônica e o texto midiático, no ambiente virtual, em uma abordagem dialógica, permeando sobre o tema livre, com intuito de motivar o aluno à leitura e à produção textual. Nessa perspectiva, o objeto da nossa pesquisa se baseia na crônica produzida por um aluno e que está relacionado ao AVA. Portanto, mesmo não se tratando de "conteúdos midiáticos", todavia, de temas de interesse didáticos, são apropriados e colocados em circulação online.

A ferramenta digital é um ambiente público constituído por comunidades semióticas, ou seja, comunidades de vozes reunidas em torno de temas, são várias vozes representadas por meio de fragmentos de texto sobre o assunto abordado. Tal ambiente público é dialógico, pois veiculam vozes que apresentam opiniões e manifestações sociais, podendo adquirir um discurso de valor (DALLARI, 2010, p. 4). 
Portanto, este artigo pretende fazer uma apresentação a respeito das peculiaridades da linguagem escrita, pois segundo Dorsa (2010), a linguagem no AVA é basicamente escrita, bem como a apresentação dos diferentes níveis de linguagem, assim como a função de cada um e seus diferentes usos e características. É importante observar o que Dorsa (2010) pontua:

\begin{abstract}
O ambiente virtual de aprendizagem é um espaço propício para se ensinar e aprender, pois redimensiona o papel de cada membro no uso da interação, participação, colaboração e autonomia. Ressalta-se, portanto, o aspecto dialógico da linguagem, pois, a situação discursiva e o contexto obrigam o locutor a moldara a sua enunciação de acordo com as condições externas (DORSA, 2010, p.48).
\end{abstract}

De acordo com esta autora, no ambiente virtual, o aprendiz faz uso de diferentes ferramentas para se comunicar. Este tipo de interação é utilizado nos hipertextos digitais, é um estilo não linear, promove acessibilidade aos acervos digitais, tem uma linguagem própria globalizada e o discurso se aproxima da oralidade. Essas características são favoráveis à aprendizagem, visto que partem dos usuários do espaço cibernético através de uma linguagem própria com muitos termos típicos que são comuns aos usuários facilitando a globalização e consequentemente a difusão da aprendizagem no ambiente virtual. Em vista disso, ela assinala que "muito raramente, um texto é resultado do trabalho de apenas uma pessoa. As diferenças discursivas são negociadas nos textos; elas são regidas por diferenças de poder que são, elas mesmas, em parte codificadas e determinadas pelo discurso e pelo gênero" (DORSA, 2010 p.30).

O AVA/IA devem proporcionar o conhecimento autodirigido, e para isso a linguagem utilizada pelo docente deve ser capaz de romper barreiras de comunicação e inibições existentes no ensino presencial. Desta forma, observou-se que é primordial que os participantes de um curso no formato EAD tenham em mente que a eficácia da comunicação será alcançada a partir do momento que souberem utilizar a linguagem, considerando as variações existentes nos níveis de linguagem bem como nas funções de linguagem aqui elencadas, como afirmam Teixeira e Araújo (2019):

Por muito tempo os profissionais em educação vêm buscando e experimentando formas de equacionar essas teorias com o dia a dia em sala de aula. A informática ou o uso do computador vem a ser mais uma ponte no estreitamento da relação teoria-prática. A versatilidade na manipulação do computador permite que o indivíduo possa vivenciar e realizar experimentos ou produzir textos, ou realizar pesquisas sobre temas aos quais nunca poderia ter acesso através de meios reais ou mesmo cuja realização demandaria uma infra-estrutura inviável à maioria das escolas. Além disso, o computador permite tanto a realização de operações individuais, onde o educando vai navegando por assuntos do seu interesse quanto uma socialização através do relacionamento com pessoas distantes tanto geograficamente como muitas vezes culturalmente. Para que isso tudo aconteça é necessário um conhecimento mínimo no uso do computador, conhecimento esse facilitado pelo uso de interfaces 
cada vez mais simbióticas com o usuário (TEIXEIRA e ARAUJO, 2019, p. 04).

Portanto, para que a aprendizagem aconteça de forma satisfatória em um Curso mediado pelas Tecnologias da Informação e Comunicação, Dallari (2010) assegura que é primordial que os participantes (tanto docentes e tutores, quanto alunos) tomem consciência da importância da utilização dos recursos linguísticos disponíveis, visto que a comunicação em Ambiente Virtual se dá, em grande parte do tempo, através da linguagem escrita, porque os envolvidos neste processo de aprendizagem não estarão o tempo todo síncronos, e sim assíncronos (DALLARI, 2010, p. 27). É através da linguagem escrita dos chats, fóruns, emails e atividades enviadas que se dá a interação entre docente e aluno

\section{Metodologia e análise do corpus do estudante}

A crônica do aluno é analisada a partir das marcas da oralidade, como progressão tópica, marcadores de opinião, dentre outras, relacionando-as com as características da crônica em diferentes perspectivas. Observamos, também, o enquadramento dos marcadores conversacionais, uma vez que, por meio deles, são produzidos efeitos de sentido.

\subsection{Análise e interpretação do corpus}

Neste item nos voltaremos à análise do nosso corpus constituído de um texto produzido no sistema AVA, por um estudante da EAD.

\section{Texto}

\section{Poluição nas Águas}

E verdade que se não houvesse tantas poluições nos rios, lagos, mares água não estaria acabando tão de presa, eu ver no jornal um lugar em São Paulo quase não tem água em quanto em outros lugares o povo acha que e brincadeira pois na falta de água que teve aqui em Aracaju quando cometaram o caso, eu estava passando e ver uma pessoal lavando a causada como não tivesse acontesedo nada e eu vir aquilo e fiquei besta pois nem tinha chegado água direito, também não só tem as que agente tem que mudar a nossa forma de pensar, não e porque não foi um de vocês, mais vocês tem para e pensar. Será que algum pode viver sem água? acho que não, meu tio ele tem um deposito de água mineral e nessa falta de água todo mundo querendo água para tomar banho e etc... o povo achava que ele não queria vender a água mais era porque agente tambem tem nossos clientes, também tinha a roto para fazer. mais o povo não tava nem ai tinha vez que meu tio mim chamava cinco horas da manha, para mim ir ajuda lo agora eu mim pergunto sim que água e importante mesmo eu acho que sim, porem olhem pense antes de estruir alguma coisa que e importante, não so para mim, mais para todos nois.

\section{Análise do texto}

\section{As categorias semântico-discursivas de tempo e de aspecto no uso de verbo}


Segundo Vargas (2017), o estudo das categorias de tempo e de aspecto, consideradas em sua dimensão semântico-discursiva, pode contribuir para que o indivíduo desenvolva a competência linguística e saiba compreender e utilizar os mecanismos disponíveis na língua para criar sentido (VARGAS, 2017, p. 01). Temos os seguintes trechos:

“eu ver no jornal um lugar em São paulo quase não tem água'

"porque agente também tem nossos clientes, também tinha a roto para fazer

também não só tem as que agente'.

Percebemos que se instaura no texto um sujeito/locutor que assume o papel de narrador dos fatos ocorridos no mundo real e que, para isso, faz uso das formas verbais, instigando seu interlocutor a participar da construção de sentido do texto.

O locutor pode ou não relacionar o relato com o tempo passado, uma vez que a narração dos fatos é indiferente ao tempo cronológico. Essa ideia se comprova com as construções no presente nos trechos e que deveriam ser apresentadas por meio de formas verbais do passado, indicando ações concluídas, porém não são:

"Eu estava passando e ver uma pessoal lavando a causada como não tivesse acontecendo nada e eu vir aquilo e fiquei besta pois nem tinha chegado água direito".

A intenção em prolongar a descrição do ambiente, no texto, reforça-se com a presença da locução verbal de gerúndio e particípio destacados. Denota seu valor intrínseco, provocado por esse uso, as ações se prologam, não acabam, projetam-se para o presente.

\section{Progressão tópica}

Os problemas referentes à sequenciação tópica ${ }^{11}$ acontecem também com a dispersão tópica, marcada pela dificuldade de o autor manter o foco no mesmo tema. Leiamos esses trechos:

"E verdade que se não houvesse tantas poluições nos rios, lagos, mares água não estaria acabando tão de presa [...]".

“[...] pois na falta de água que teve aqui em aracaju quando cometaram o cas, eu estava passando e ver uma pessoal lavando a causada como não tivesse acontesedo nada".

\footnotetext{
${ }^{11}$ A noção de sequenciação tópica se aplica também ao enunciado do texto analisado. De acordo com Lins (2006), cada enunciado, numa sequência conversacional, é tópica, semântica ou pragmaticamente relevante para o enunciado diretamente seguinte ou precedente a conversa como um todo se apresenta como coerente (LINS, 2006, p. 126).
} 
“[...] meu tio ele tem um deposito de água mineral e nessa falta de água todo mundo querendo água para tomar banho e etc. o povo achava que ele não queria vender a água mais era porque agente tambem tem nossos clientes, também tinha a roto para fazer".

Ao tratar da poluição das águas, no decorrer da crônica, percebemos que ele faz um salto temático e passa a discutir sobre a falta de água. Tanto a dificuldade em expandir os subtópicos, como a dispersão temática, constituem obstáculos na criação de um contexto sociocognitivo mais amplo, necessário à expansão do tópico. Assim, o cronista não consegue definir o enfoque, nem estabelecer o roteiro do texto, e os efeitos são a dispersão e a falta de aprofundamento.

\section{Marcadores de opinião}

Para Marcuschi (2004), os marcadores de opinião são representados por expressões constituídas com um verbo de valor epistêmico (acho que) ou de percepção (vejo que) ou, ainda, por uma expressão adverbial (na minha opinião) (MARCUSCHI, [1986], 2004, p.289). Com esses marcadores, o autor assinala não apenas seu ponto de vista, mas também sua presença no texto:

“[...] acho que não, meu tio ele tem um deposito de água mineral e nessa falta de água todo mundo querendo água para tomar banho e etc... o povo achava que ele não".

"[...] mesmo eu acho que sim, porem olhem pense antes de estruir alguma coisa que e importante, não so para mim, mais para todos nois".

Percebemos que o autor aponta a sua presença por meio da subjetividade, que constituem característica da realização falada que, para Preti (2009), são os significados interpessoais, por meio dos quais os falantes se inserem no discurso (PRETI, 2009, p. 257). Além disso, esses marcadores apresentam dois empregos: o primeiro representa um palpite (semelhante a supor), e o segundo um julgamento (considerar, julgar). No exemplo citado, tem-se antes o palpite, a falta de convicção, pois o aluno não procura sustentar a sua opinião (PRETI, 2009, p. 258).

\section{Aspectos jurídicos de programas de computador e Inteligência artificial}

Inteligência artificial e a propriedade intelectual: criador de robô (robô criatura) e robô criador, eis aí o grande e instigante desafio para os legisladores, pois o sistema IA não só tem a capacidade de armazenamento e manutenção de dados, como também, as funções de adquirir, representar e manipular conhecimento e com isto resolver problemas complexos ( engenharia do conhecimento). O ser humano não está se apercebendo que de criatura está se tornando criador? E a sua criatura deverá pleitear ter uma personalidade dentro do universo jurídico além das já existentes, a natural e jurídica. Podemos então falar de personalidade robótica. 
$\mathrm{Na}$ propriedade intelectual, o que se vai proteger, ou seja, o que se vai inserir na proteção no ordenamento jurídico, é a criatividade humana até atingir o seu ponto máximo da exploração econômica, que é a sua aplicação industrial, que é um dos requisitos para análise de pedido e posterior concessão de patente.

Na nossa Carta Magna de 1988, a propriedade intelectual é tratada no art. 5 e nos incisos abaixo descritos:

Art. $5^{\circ}$ Todos são iguais perante a lei, sem distinção de qualquer natureza, garantindo-se aos brasileiros e aos estrangeiros residentes no País a inviolabilidade do direito à vida, à liberdade, à igualdade, à segurança e à propriedade, nos termos seguintes:

IV - é livre a manifestação do pensamento, sendo vedado o anonimato;

XXII - é garantido o direito de propriedade;

XXIII - a propriedade atenderá a sua função social; XXVII - aos autores pertence o direito exclusivo de utilização, publicação ou reprodução de suas obras, transmissível aos herdeiros pelo tempo que a lei fixar;

XXIX - a lei assegurará aos autores de inventos industriais privilégio temporário para sua utilização, bem como proteção às criações industriais, à propriedade das marcas, aos nomes de empresas e a outros signos distintivos, tendo em vista o interesse social e o desenvolvimento tecnológico e econômico do País.

$\mathrm{O}$ artigo 5 e seus incisos são e serão balizas para as futuras leis que tratam do assunto e que transversalmente irão afetar de forma direta e indireta todas as criações surgidas e criadas pelo ROBOT.

No ordenamento jurídico brasileiro, a propriedade pode ser utilizada no que for lícito e tem função social, podendo para tanto o seu proprietário utilizar-se de todos os meios legais para protegê-la de terceiros e, em contrapartida, também não prejudicá-los. A propriedade no ordenamento brasileiro abarca tanto os bens móveis e imóveis. Este mesmo raciocínio e disposição legal são contemplados pelos ordenamentos em propriedade intelectual no Brasil. São protegidas as obras, invenções e outros produtos, frutos da criação e do espírito, quer tangível e intangível (bens imateriais) criadas por pessoas físicas e jurídicas, sujeitos capazes de contrair obrigações e deveres e ter direitos. Fato que por si só, não contempla a criatura criada pelo Homem, o ROBOT, fruto da inteligência natural do homem. ROBOT, como uma nova modalidade de sujeito, que adquire personalidade diversa das existentes, personalidade robótica ${ }^{12}$, porém, ab initio, com os mesmos efeitos em termos de natureza patrimonial dos bens criados porque a IA pode vir a ser autônoma, ou já é autônoma na criação de suas obras e inventos, ao utilizar os sistemas de algoritmos.

12 Na comunidade europeia, este assunto já vem sendo tratado, pelo Parlamento Europeu . 
Logo, pode-se afirmar que a natureza jurídica do ROBOT seria a de um objeto material de vida algorítmica e que também poderia ser sua obra derivada do espírito algorítmico. ${ }^{13}$

Enquanto a comunidade internacional especialista das áreas se encaminha nos primeiros passos jurídicos em elaborar leis, regulamentos, Declaração, em relação aos direitos e deveres do Robot, vamos analisar as leis que tratam da proteção de bens imateriais vigentes pelas regras da propriedade Intelectual (propriedade de criação literária e propriedade industrial).

\section{Direito Autoral, programas de computador, LGPD e MP da liberdade econômica.}

A lei que trata de programas de computador ${ }^{14}$ é a lei $9.609 / 1998$, tendo esta, 16 (dezesseis) artigos. Nos seus art. 2, artigo 4 e parágrafos e por fim o art. 5 tratam da proteção do programa de computador e a propriedade deste respectivo programa e em nenhum momento, a lei fala de obras criadas pelo Robot, pelos sistemas de inteligência. Em nenhum momento na lei brasileira de programa de computador trata de obras derivadas de sistema de inteligência artificial, porém com a lei de direito autoral, este impasse jurídico foi resolvido, conforme veremos adiante ao analisar a lei 9610/1998.

Esta mesma postura jurídica fora contemplada pela mais nossa recente lei que trata de proteção de dados, por não contemplar quaisquer outras obras elaboradas por esta criatura robótica, conforme o art. 1 da lei 13709/2019 e também pela MP 881/2019. Já a MP não contempla em nenhum momento em sistema de inteligência artificial. No entanto, a lei $13709 / 2019$ por forma direta, mas não explícita com maiores detalhes, contempla outro meio de tratamento de dados. Já prevê que os dados sejam tratados por outro meio, como os sistemas. No entanto, porém mais adiante, no seu artigo 17, só contempla que somente a pessoa natural é a titular dos seus dados pessoais. Pergunta-se? E o robot com sua personalidade robótica? Pode vir a ser titular de seus dados? E quanto ao movimento de Open Souce, de quem será a titularidade, afinal a obra surgida poderá ter sido elaborada por várias pessoas, por vários sistemas de inteligência artificial? $\mathrm{O}$ criador originário do programa convida outros indefinidamente a participarem de sua obra, fato que faz surgir uma obra livre. ${ }^{15}$

Este fato precisa ser enfrentado pelos juristas e definido, posto em leis e gerar os efeitos legais. No entanto, as partes envolvidas em criações derivados de sistemas de

\footnotetext{
${ }^{13}$ A nossa lei quer de direito autoral fala que o sistema de computador cria obra de espírito, como no direito francês que contempla a possibilidade do computador, seus programas de computador serem consideradas como obras do espírito conforme preceitua o L. 112-2 inciso 13 do Código de Propriedade Intelectual .

“Article L112-2, inciso 13. Modifié par Loi n94-361 du 10 mai 1994 - art. 1 JORF 11 mai 1994.Sont considérés notamment comme oeuvres de l'esprit au sens du présent code:

$13^{\circ}$ Les logiciels, y compris le matériel de conception préparatoire ;"'

14 Há uma separação legal entre hardware e software. Como dia Manoel Joaquim Pereira dos Santos. "Embora á primeira vista os dois conceitos pareçam claramente distintos, existe uma zona fronteiriça que ao longo dos tempos desafiou os estudiosos do tema. Com efeito, vimos anteriormente que, do ponto de vista técnico, o termo hardware compreende os elementos físicos do sistema de computação, enquanto que o software, os elementos lógicos, dos quais o programa de computador é a parte central.” SANTOS. Manoel J. P. A proteção autoral de programas de computador, Lumen juris: Rio de Janeiro, 2008, p.135.

${ }^{15}$ No Brasil tem-se o exemplo do LINUX.
} 
inteligência têm outra via de partilhar, difundir, vender sua obra com plena liberdade, que é a capacidade empresarial de contratar. ${ }^{16}$

O movimento open source se desenvolveu e acabou que um grupo resolveu criar um site, um movimento Open Robot Harware que disponibiliza ao público tanta a parte física (harware) como a parte programática (software) fato que incentiva a aplicação da robótica , informática na seara educacional, tema central do presente artigo. ${ }^{17}$

Já a nossa lei de direito autoral - lei 9610/1998 inclui no rol das criações de espírito, as obras derivadas de programas de computador apesar de que no seu Parágrafo 1 diz que o programa de computador em sua legislação específica e ser-lhe-iam aplicadas disposições que lhe sejam compatíveis. E, na parte de revogação de leis, a lei autoral contempla de forma genérica a revogação a lei de programa de computador, para considerar "criações de espírito", obras decorrentes de um robot. ${ }^{18}$

A pergunta que inquieta e que se faz, é que se o regime de direito autoral se aplica a uma obra oriunda de um robot e aperfeiçoada por vários sistemas também? A jurisprudência francesa tem entendido como o criador originário foi um ser humano, será aplicada por extensão o regime do direito autoral.

\section{E, se, a criação for criada somente por um Robot?}

Se se considerar o Robot como desprovido de qualquer personalidade, atribuirá a titularidade ao humano originário do programa, no entanto ao contemplar-se a personalidade robótica, a lei disciplinará com todos os rigores e requisitos legais, mudando inclusive o Código Civil ao criar outra personalidade, a de personalidade robótica além da natural que é que a pessoa física detém e a jurídica conferida a vários entes como sociedades, associações e fundações e outros. Então porque não se conferir personalidade robótica ao robot inteligente? $\mathrm{Na}$ França os animais são considerados "seres sensíveis, logo, teremos brevemente em vários ordenamentos jurídicos, a personalidade robótica.

Google entrou com pedido de patente, nos Estados Unidos, referente a dar personalidade com características humanas aos futuros robots. "Le géant américain de l'Internet qui depuis quelques années investit énormément dans la robotique et l'intelligence artificielle, vient en effet de déposer un brevet permettant, dans un avenir non défini, de télécharger différentes personnalités pour les futurs robots domestiques." 19

\footnotetext{
16 Recentemente foi posta em vigência a MP 881 de 30 de abril de 2019, sobre a Liberdade econômica que tratou substancialmente da área de contratos, porém cometendo o mesmo equivoco de não incluir o ROBOT , nos titulares de direito. Ao ser contratado o programa /sistema originário pode-se optar pela distribuição e acesso livre., ou seja, uma obra aberta a todos indiscriminadamente. O que a lei pode impedir, a obra aberta pode resolver, através de licenças livres, com cláusulas estipuladas no contrato. Deve-se conciliar também os interesses econômicos e também os interesses de obras realizada pelo robot e depois aperfeiçoadas por outros robots.

${ }^{17} \mathrm{http}$ //www.openrobothardware.org/ "Open Robot Hardware is intended to serve as a resource for efforts focusing on open source mechanical and electrical hardware, with a particular focus on projects that may be useful in robotics applications, robotics research and education."

18 Pessoalmente não considero "criações de espirito" e sim criações originárias de um objeto material (robot) de vida algorítmica com personalidade robótica.

19 https://www.lesechos.fr/2015/04/google-un-brevet-pour-doter-les-robots-domestiques-de-personnalitestelechargeables-247596
} 
Acompanhando o raciocínio já declinado acima, pode-se aplicar a lei 9679/1998 no que concerne à concessão de patente de invenção proveniente de um robot cuja patente mãe, patente dominante tivesse sido criada por um ser humano.

E, se o robot /sistema de inteligência artificial descobre um segundo uso para uma patente, e agora? Com o avanço célere da tecnologia, urge uma definição legal para a natureza jurídica do robot. Deve-se conceder-lhe a personificação robótica.

Quanto ao desenho industrial, circuito de topografia integrado e marcas, o caminho jurídico a ser percorrido.

"Enfin, l'aspect visuel d'un robot humanoïde ou animaloïde peut, en tant qu'innovation esthétique, être protégé par le droit des dessins et modèles, sous condition de nouveauté et de caractère propre. Le dépôt du nom de la création à titre de marque est encore possible." 20

Lei 9609/1998 - Lei de Programas de Computador

Art. $2^{\circ} \mathrm{O}$ regime de proteção à propriedade intelectual de programa de computador é o conferido às obras literárias pela legislação de direitos autorais e conexos vigentes no País, observado o disposto nesta Lei.

Art. $4^{\circ}$ Salvo estipulação em contrário, pertencerão exclusivamente ao empregador, contratante de serviços ou órgão público, os direitos relativos ao programa de computador, desenvolvido e elaborado durante a vigência de contrato ou de vínculo estatutário, expressamente destinado à pesquisa e desenvolvimento, ou em que a atividade do empregado, contratado de serviço ou servidor seja prevista, ou ainda, que decorra da própria natureza dos encargos concernentes a esses vínculos.

$\S 2^{\circ}$ Pertencerão, com exclusividade, ao empregado, contratado de serviço ou servidor os direitos concernentes a programa de computador gerado sem relação com o contrato de trabalho, prestação de serviços ou vínculo estatutário, e sem a utilização de recursos, informações tecnológicas, segredos industriais e de negócios, materiais, instalações ou equipamentos do empregador, da empresa ou entidade com a qual o empregador mantenha contrato de prestação de serviços ou assemelhados, do contratante de serviços ou órgão público.

$\S 3^{\circ} \mathrm{O}$ tratamento previsto neste artigo será aplicado nos casos em que o programa de computador for desenvolvido por bolsistas, estagiários e assemelhados.

Art. $5^{\circ}$ Os direitos sobre as derivações autorizadas pelo titular dos direitos de programa de computador, inclusive sua exploração econômica, pertencerão à pessoa autorizada que as fizer, salvo estipulação contratual em contrário.

Lei 13709/2019 - Lei Geral de Proteção de dados

\footnotetext{
20 Disponível em https://business.lesechos.fr/directions-juridiques/partenaire/partenaire-1701-intelligenceartificielle-et-propriete-intellectuelle-createur-de-robot-et-robot-createur-i-322639.php . Acesso em 30 mai 2019.
} 
Art. $1^{\circ}$ Esta Lei dispõe sobre o tratamento de dados pessoais, inclusive nos meios digitais, por pessoa natural ou por pessoa jurídica de direito público ou privado, com o objetivo de proteger os direitos fundamentais de liberdade e de privacidade e o livre desenvolvimento da personalidade da pessoa natural.

Art. $3^{\circ}$ Esta Lei aplica-se a qualquer operação de tratamento realizada por pessoa natural ou por pessoa jurídica de direito público ou privado, independentemente do meio, do país de sua sede ou do país onde estejam localizados os dados, desde que:

MP 881 de 30 de abril de 2019 - Liberdade Econômica

Art. $3^{0}$ São direitos de toda pessoa, natural ou jurídica, essenciais para o desenvolvimento e o crescimento econômicos do País, observado o disposto no parágrafo único do art. 170 da Constituição:

VIII - ter a garantia de que os negócios jurídicos empresariais serão objeto de livre estipulação das partes pactuantes, de forma a aplicar todas as regras de direito empresarial apenas de maneira subsidiária ao avençado, hipótese em que nenhuma norma de ordem pública dessa matéria será usada para beneficiar a parte que pactuou contra ela, exceto se para resguardar direitos tutelados pela administração pública ou de terceiros alheios ao contrato;

Lei 9610/1998 - Direitos autorais

Art. $5^{\circ}$ Para os efeitos desta Lei, considera-se:

VIII - obra:

a) em co-autoria - quando é criada em comum, por dois ou mais autores;

f) originária - a criação primígena;

g) derivada - a que, constituindo criação intelectual nova, resulta da transformação de obra originária;

h) coletiva - a criada por iniciativa, organização e responsabilidade de uma pessoa física ou jurídica, que a publica sob seu nome ou marca e que é constituída pela participação de diferentes autores, cujas contribuições se fundem numa criação autônoma;

Art. $7^{\circ}$ São obras intelectuais protegidas as criações do espírito, expressas por qualquer meio ou fixadas em qualquer suporte, tangível ou intangível, conhecido ou que se invente no futuro, tais como:

XI - as adaptações, traduções e outras transformações de obras originais, apresentadas como criação intelectual nova; 


\title{
XII - os programas de computador;
}

\section{$\S 1^{\circ}$ Os programas de computador são objeto de legislação específica, observadas as disposições desta Lei que lhes sejam aplicáveis.}

\author{
Textos aprovador pelo Parlamento Europeu em 2017
}

“59. Insta a Comissão a explorar, analisar e ponderar, na avaliação de impacto que fizer do seu futuro instrumento legislativo, as implicações de todas as soluções jurídicas possíveis, tais como:

a) Criar um regime de seguros obrigatórios, se tal for pertinente e necessário para categorias específicas de robôs, em que, tal como acontece já com os carros, os produtores ou os proprietários de robôs sejam obrigados a subscrever um seguro para cobrir os danos potencialmente causados pelos seus robôs;

b) Garantir que os fundos de compensação não sirvam apenas para garantir uma compensação no caso de os danos causados por um robô não serem abrangidos por um seguro;

c) Permitir que o fabricante, o programador, o proprietário ou o utilizador beneficiem de responsabilidade limitada se contribuírem para um fundo de compensação ou se subscreverem conjuntamente um seguro para garantir a indemnização quando o dano for causado por um robô;

d) Decidir quanto à criação de um fundo geral para todos os robôs autónomos inteligentes ou quanto à criação de um fundo individual para toda e qualquer categoria de robôs e quanto à contribuição que deve ser paga a título de taxa pontual no momento em que se coloca o robô no mercado ou quanto ao pagamento de contribuições periódicas durante o tempo de vida do robô;

e) Garantir que a ligação entre um robô e o seu fundo seja patente pelo número de registo individual constante de um registo específico da União que permita que qualquer pessoa que interaja com o robô seja informada da natureza do fundo, dos limites da respetiva responsabilidade em caso de danos patrimoniais, dos nomes e dos cargos dos contribuidores e de todas as outras informações relevantes;

f) Criar um estatuto jurídico específico para os robôs a longo prazo, de modo a que, pelo menos, os robôs autónomos mais sofisticados possam ser determinados como detentores do estatuto de pessoas eletrónicas responsáveis por sanar quaisquer danos que possam causar e, eventualmente, aplicar a personalidade eletrónica a casos em que os robôs tomam decisões autónomas ou em que interagem por qualquer outro modo com terceiros de forma independente;"21

"Ce thème fait partie de la question plus générale de l'adaptation du droit, et en particulier du droit de la propriété intellectuelle, aux évolutions technologiques. La relation que les robots entretiennent avec la propriété intellectuelle présente deux facettes. D'un côté, les robots peuvent être considérés en tant qu'objet de propriété intellectuelle. Un robot chirurgical, par exemple, est brevetable comme toute nouvelle machine. Un droit d'auteur peut être revendiqué sur son aspect extérieur s'il est original. Les données qu'il mémorise constituent une base de données également protégeable par la propriété intellectuelle. Mais, d'un autre côté, et c'est l'aspect le plus intéressant du sujet, se pose la question de l'accession des objets créés par le robot à la protection par le droit d'auteur ou par le droit des brevets. En effet, du fait des progrès de l'intelligence artificielle, les robots deviennent de plus en plus autonomes. Un objet créé par un robot, sans intervention humaine, est-il une œuvre de l'esprit couverte par le droit d'auteur? Une invention réalisée par une machine autonome est-elle brevetable ? Dans ce cas qui sera désigné comme étant le titulaire des droits de propriété intellectuelle ? Ce sont ces questions que cet article se propose d'explorer."22

\footnotetext{
${ }^{21}$ Disponível em http://www.europarl.europa.eu/doceo/document/TA-8-2017-0051_PT.html?redirect, acesso em 05 jul 2019.

22 [1] Résolution du Parlement Européen du 16 février 2017 contenant des recommandations à la Commission concernant des règles de droit civil sur la robotique (2015/2103(INL))

[2] La méthodologie appliquée ici est basée sur le principe d'application distributive des droits de PI, dégagé par la jurisprudence pour les jeux vidéo, œuvres composées de plusieurs éléments aux régimes juridiques différents et qualifiés d'œuvres complexes (Cass. 1è).
} 


\section{CONCLUSÃO}

A leitura e a análise da crônica do estudante, pautada na temática livre e numa modalidade virtual, podem contribuir de forma a motivar os alunos ao ensino-aprendizagem, bem como contribuir para que o professor repense sua prática educativa ou a confirme. Diversas ferramentas promovem a comunicação em ambientes de educação a distância-AED e a utilização dos recursos do sistema AVA proporciona uma nova forma de escrita, levando o aprendiz a pensar sobre o próprio pensar, favorecendo maior conhecimento sobre o assunto.

O uso das novas tecnologias exige trabalhar em sala de aula com investigação, com interatividade e colaboração entre os envolvidos no processo de ensino-aprendizagem e que estimula um processo de mudança de comportamento tanto do professor quanto do aluno, o que os leva a adotarem uma postura de compartilhamento do desejo de construir e aprender, capaz de realizar a atribuição de significados importantes para sua articulação dentro do universo escolar.

Nesse contexto, o sistema online de aprendizagem requer que o aprendiz precise apresentar características como: iniciativa, motivação, autodisciplina e autonomia. A autonomia, segundo Sloczinski e Chiaramonte (2005), é uma das habilidades fundamentais para o cidadão da atualidade e a utilização de ambientes virtuais de aprendizagem, associada a uma metodologia adequada, favorece o desenvolvimento dessa característica no aprendiz, conforme preceituam autores de escol citados no presente artigo.

A comunidade internacional caminha a passos largos para a elaboração de leis no tocante à propriedade intelectual e vários outros ramos do direito, no tocante aos robots. Urge de lege ferenda. É necessário que o mundo se antecipe aos procedimentos éticos e antiéticos dos inventores dos robots e crie leis que regulem todos os aspectos envolvendo direitos do robot para não se ficar sem resposta efetiva jurídica.

"Il appartient maintenant au législateur de prendre position. « Soit de légiférer pour tenir compte d'une spécificité et créer des règles propres à la protection des créations réalisées par des technologies robotiques, position envisagée par la Commission des affaires juridiques du Parlement européen ; soit d'accepter l'idée d'une déperdition de valeur de ces créations en courant le risque de les voir tomber instantanément dans le domaine public $»{ }^{23}$

\section{REFERÊNCIAS}

BARBOSA, Denis Borges. Direito de autor, Rio de Janeiro, Lumen juris: 2013.

23 BONET, Eric. La robotique confrontée à la propriété intellectuelle. Disponível em https://www.alain-bensoussan.com/avocats/propriete-intellectuelle-robotique/2016/09/16/ Acesso em 29 mai 2019. 
BARBOSA, Denis Borges. Tratado da Propriedade Intelectual, Tomo III, Rio de Janeiro: Lumen Juris Editora:, 2010, 2192 p.

BARBOSA, Pedro Marcos Nunes e Beatriz Bezerra . Breves tópicos sobre a 'regulação' da vida cotidiana pelos algoritmos, privacidade e segurança jurídica. Disponível em http://www.gedai.com.br/wp-content/uploads/2019/05/018-BREVES-T\%C3\%93PICOSSOBRE-A-\%E2\%80\%98REGULA\%C3\%87\%C3\%83O.pdf, Acesso em 23 jun 2019.

BARROS, Carla Eugenia Caldas. Manual de Direito da propriedade Intelectual, Aracaju: Evocati, 2007, 702 p.

BARROS, Carla Eugenia Caldas. Afinal software é mercadoria ou não? Disponível em http://www.pidcc.com.br/artigos/1003/041003.pdf, Acesso em: 01 out. 2018.

BARROS, Carla Eugenia Caldas. Software em sede de direito tributário internacional e de propriedade intelectual Disponível em http://www.pidcc.com.br/artigos/1003/051003.pdf, acesso em: 01 out. 2018.

BARROS, Carla Eugenia Caldas. A globalização tributária: o dever fundamental de pagar imposto e o direito fundamental de acesso a novas tecnologias. Disponível em http://www.pidcc.com.br/artigos/07022016/05072016.pdf, acesso em: 01 out. 2018.

BARROS, Carla Eugenia Caldas. A propriedade intelectual derivada da criação e do trabalho intelectual. Disponível em http://pidcc.com.br/artigos/052014/13052014.pdf, acesso em: 01 out. 2018.

BAKHTIN, M. Problemas da poética de Dostoiévski. Tradução de Paulo Bezerra. Rio de Janeiro: Forense Universitária, 2008.

BERTRAND, André R. Droit d'auteur, Paris: Dalloz,2012.

BINCTIN, Nicolas, Droit de la proprieté intellectuelle Issy les Moulineaux: LGDJ, 2016.

BONET, Eric. La robotique confrontée à la propriété intellectuelle. Disponível em https://www.alain-bensoussan.com/avocats/propriete-intellectuellerobotique/2016/09/16/

CARDOSO, Nubia Poliane Cardoso e Araújo, Alberto Einstein . Informática e Educação: uma reflexão sobre novas tecnologias. Disponível em http://www.hipertextus.net/volume1/artigo13-nubia-alberto.pdf, Acesso em: 05 abr. 2019.

DALLARI, Bruno B. A. Mídia, Cidadania e as novas práticas de letramento. 2010.

DORSA, A. C. Linguagem mediada pelas Tecnologias da Informação e Comunicação. Campo Grande, MS: UCDB/Portal Educação, 2010.

FONSECA, R. S. A construção de sentidos no texto escrito: um estudo das estratégias textual-discursivas na crônica de Lya Luft. Cadernos de Letras da UFF - Dossiê: Linguagens em diálogo $\mathrm{n}^{\mathrm{o}}$ 42, p. 109-131, [1992], 2011. Disponível em: 
ANÁLISE DE UMA CRÔNICA PRODUZIDA POR UM ALUNO NO AMBIENTE VIRTUAL DE

APRENDIZAGEM-AVA/ Direito e INTELIGÊNCIA ARTIFICIAL

E-ISSN 2316-8080

http://www.cadernosdeletras.uff.br/joomla/images/stories/edicoes/42/artigo7.pdf. Acesso em: 07 jan. 2019.

FRAZÃO, Ana. Quais devem ser os parâmetros éticos e jurídicos para a utilização da inteligência artificial? Disponível em http://estadodedireito.com.br/quais-devem-ser-osparametros-eticos-e-juridicos-para-a-utilizacao-da-inteligencia-artificial/, Acesso em 01 maio 2019.

FRAZÃO, Ana. Algoritmos e inteligência artificial. São Paulo: Ed. Singular, 2019.

GNERRE, M. Linguagem, escrita e poder. 4ª ed. São Paulo: Martins Fontes, 1998.

KAUFMAN, Dora. Inteligência artificial: questões éticas a serem enfrentadas. Disponível em. https://dorakaufman.blog/wp-content/uploads/2018/05/INTELIGENCIAARTIFICIAL-QUESTOES-ETICAS-A-SEREM-ENFRENTADAS.pdf, Acesso em: 02 abr. 2019.

Wachowicz, Marcos . Patente do Software seria um instrumento de desenvolvimento e de inovação ?, Disponível em http://www.gedai.com.br/artigos/atenteabilidade-do-software-comoinstrumento-de-desenvolvimento-e-de-inovacao-artigo-de-marcos-

wachowicz/?fbclid=IwAR3PICROf7D1HZXbPtCFyCYvfaQzj-

o1IXXeZU90Azk1FBFsg5hgHvB4TPA, Acesso em 18 jun 2019.

LINS, M. O tópico discursivo em charges diárias. Cadernos do CNLF, vol. XVI, no 4 , t.1 - Anais do XVI CNLF, pag. 1013-1023, 2006. Disponível em: http://castelobrancocientifica.com.br/img.content/artigos/artigo85.pdf. Acesso em: 23 mai. 2017.

MAGRANI, Eduardo. A internet das Coisas, Rio de Janeiro: FGV editora rio, 2018, 192 p.

MARCUSCHI, L. A. Análise da Conversação, 4 ed. São Paulo: Ática, [1986], 2004

MASSENO, Manuel David, Protegendo os cidadãos $\square$ consumidores em tempos de big data: uma perspectiva desde 0 direito da união EUROPEIA https://www.academia.edu/37322493/Protegendo_os_cidad\%C3\%A3os-

consumidores_em_tempos_de_big_data_uma_perspectiva_desde_o_direito_da_Uni $\%$ C $3 \%$ A3o_Europeia, acesso em: 09 set. 2018.

MASSENO, Manuel David .Assuring Privacy and Data Protection within the Framework of Smart Tourism Destinations, https://www.academia.edu/37322445/Assuring Privacy and Data Protection within the F ramework of Smart Tourism Destinations, Acesso em: 09 set. 2018.

NEVEJANS, Nathalie, Traité de Droit et d'éthique de la robotique civile, Bordeaux : Leh Édition, , 2017, $1231 \mathrm{p}$. 
MEDEIROS. L. A escrita: construção e evolução no tempo. Disponível: http://www.webartigos.com/artigos/a-escrita-construcao-e-evolucao-no-tempo/20103/.

Acesso em: 20 de jul. 2016.

MEDEIROS, Heloísa Gomes e Letícia Canut. Analise das funções dos algoritmos nas relações de consumo na Internet, Disponível em http://www.gedai.com.br/artigos/analisedas-funcoes-dos-algoritmos-nas-relacoes-de-consumo-nainternet/?fbclid=IwAR3jiCpe4DSCJMSoGcpGA9muqMTSnhgoj4HOXIhhFPusIxVKy84iR kGJAD0, Acesso em 17 jun 2019.

MEDEIROS, Heloisa Gomes e leticia Canut. O direito de autor sobre o software e suas implicações sobre a governança dos algoritmos. Disponível em http://www.gedai.com.br/wp-content/uploads/2019/05/021-O-DIREITO-DE-AUTORSOBRE-O-SOFTWARE-E.pdf, acesso em 23 jun2019.

MONARD/ILTC e Baranauskas, José Augusto. Aplicações de Inteligência artificial: uma visão geral. Disponível em: http://dcm.ffclrp.usp.br/ augusto/publications/2000-laptec.pdf. Acesso em: 02 abr. 2019.

MORAN, J. M. Relatos de experiências como utilizar a Internet na educação. In: V. 26 n. 2, Brasília, DF, 2004. Disponível em: http://revista.ibict.br/ciinf/article/view/700/709. Acesso em: 7 jan. 2019

PRETI, D. (Org.). Oralidade em textos escritos. São Paulo: Humanitas, 2009.

PUREN, C. Nouvelle perspective actionnelle et (nouvelles) technologies éducatives: quelles convergences. et quelles divergens? - Conférence donnée au Colloque CyberLangues 2009 à Reims le 25 août 2009. Disponível em: https://www.aplvlanguesmodernes.org/spip.php?article2673. Acesso em: 15 de jan. 2019.

PUREN C. Perspective actionnelle et formation des enseignants: pour em finir avec le CECR - À propos de: ROBERT Jean-Pierre, ROSEN Évelyne, REINHARDT Claus, Faire classe em FLE. Une approche actionnelle et pragmatique (Paris: Hachette-FLE, 2011, 192 p.) disponível em: https://www.christianpuren.com/mes-travaux/2012b. Acesso em: $28 \mathrm{de}$ fev. 2019.

REIS , Luiza Daniele Monteiro dos. Limites éticos na utilização da inteligência artificial e o impacto na sociedade informacional: análise da resolução do parlamento europeu sobre disposições de direito civil sobre robótica (2015/2103 - inl), Disponível em http://www.gedai.com.br/wp-content/uploads/2019/05/024-LIMITES-\%C3\%89TICOS-NAUTILIZA \%C3\%87\%C3\%83O-DA.pdf, acesso em 20 jun 2019

ROCHA, J. De que forma a inteligência artificial pode ser utilizada pelo bem da educação?, Disponível em: http://info.geekie.com.br/inteligencia-artificial-educacao/. Acesso: 25 de fev de 2019. 
SANTOS, Manoel Joaquim Pereira dos. A proteção autoral de programas de computador, Lumen juris, Rio de Janeiro, 2008. 454 p.

SILVA, J. D. Tecnologia e educação: artefatos tecnológicos na dependência de mediadores transformadores. In: APASE, Ano XI no 26 - outubro de 2010, p. 7-10.

SILVA, Ivan de Souza et al A importância da Inteligência Artificial e dos sistemas especialistas. $\quad$ Disponivel em

http://www.abenge.org.br/cobenge/arquivos/15/artigos/09 158.pdf, Acesso em: 03 abr.2019.

SCHIRRU, Luca. A Inteligência Artificial e o Big Data no Setor da Saúde: Os Sistemas $\begin{array}{lllll}\text { Especialistas } & \text { e } & \text { o } & \text { Direito, } & \text { Disponível }\end{array}$ http://www.pidcc.com.br/artigos/1003/061003.pdf, Acesso em: 20 abr. 2019.

SCHIRRU, Luca. Inteligencia artificial e o direito autoral: o domínio público em perspectiva, Disponível em Academia. Edu.

SLOCZINSKI, H.; CHIARAMONTE, M. S. Ambiente virtual: interação e aprendizagem. Informática na Educação - teoria \& prática, v. 8, n. 1, UFRGS, Porto Alegre, 2005.

TRINDADE, A. P. P. O processo histórico da escrita e sua importância na formação do sujeito. Disponível em: http://www.planetaeducacao.com.br/portal/gepi/processo historico da escrita.pdf. Acesso em: 08 abr. 2016.

VANBRABANT, Bernard, La proprieté Intellectuelle - Nature juridique, Tomo I, Bruxelles: Groupe Larcier S.A, 2016, 662 p.

VARGAS, M. V. A. M. O ensino do verbo: tempo e aspecto como categorias semânticodiscursivas, 2017. Disponível em: file:///C:/Users/login/Downloads/62347-81257-1SM.pdf. Acessado 03 jan 2017.

WACHOWICZ, Marcos. Propriedade Intelectual de Software e Revolução da Tecnologia da Informação, Curitiba, Editora Juruá, 2005, 287 p. 